\title{
MOLECULAR STRUCTURE AND \\ INTERACTIONS OF NUCLEIC ACID COMPONENTS IN NANOPARTICLES: $A B$ INITIO CALCULATIONS
}

\author{
YU.V. RUBIN, L.F. BELOUS
}

PACS 61.46.Bc, 78.67.Bf

B. Verkin Institute for Low Temperature Physics and Engineering,

Nat. Acad. of Sci. of Ukraine

(C) 2012

(47, Lenin Ave., Kharkiv 61103, Ukraine; e-mail: rubin@ilt. kharkov. ua)

Self-associates of nucleic acid components (stacking trimers and tetramers of the base pairs of nucleic acids) and short fragments of nucleic acids are nanoparticles (linear sizes of these particles are more than $10 \AA$ ). Modern quantum-mechanical methods and softwares allow one to perform $a b$ initio calculations of the systems consisting of 150-200 atoms with enough large basis sets (for example, $\left.6-31 \mathrm{G}^{*}\right)$. The aim of this work is to reveal the peculiarities of molecular and electronic structures, as well as the energy features of nanoparticles of nucleic acid components.

We had carried out $a b$ initio calculations of the molecular structure and interactions in the stacking dimer, trimer, and tetramer of nucleic base pairs and in the stacking ( TpG)(ApC) dimer and $(\mathrm{TpGpC})(\mathrm{ApCpG})$ trimer of nucleotides, which are small DNA fragments.

The performed calculations of molecular structures of dimers and trimers of nucleotide pairs showed that the interplanar distance in the structures studied is equal to $3.2 \AA$ on average, and the helical angle in a trimer is approximately equal to $30^{\circ}$. The distance between phosphor atoms in neighboring chains is $13.1 \AA$. For dimers and trimers under study, we calculated the horizontal interaction energies.

The analysis of interplanar distances and angles between nucleic bases and their pairs in the calculated short oligomers of nucleic acid base pairs (stacking dimer, trimer, and tetramer) has been carried out. Studies of interactions in the calculated short oligomers showed a considerable role of the cross interaction in the stabilization of the structures. The contribution of cross interactions to the horizontal interactions grows with the length of an oligomer. Nanoparticle components get electric charges in nanoparticles. Longwave low-intensity bands can appear in the electron spectra of nanoparticles.

\section{Introduction}

Self-associates of nucleic acids (stacking trimers and tetramers of nucleic acid base pairs) and short NA fragments are nanoparticles ((linear sizes of these particles are more than $10 \AA)$. Modern quantum-mechanical methods and programs allow one to perform the $a b$ initio calculations of systems consisting of 150-200 atoms with a rather large basis $\left(6-31 \mathrm{G}^{*}\right.$, for example) [1-3].
Earlier, the $a b$ initio calculations were carried out for nucleic acid base pairs and for dimers of nucleic acid base pairs [4-10]. But the sizes of these structures are less than $10 \mathrm{~nm}$, and these structures cannot be considered as nanoparticles. Work [11] presents the results of calculations for interaction energies of an oligomer including 7 pairs of nucleic acid bases. But, in those calculations, the oligomer geometry was not optimized, being taken from NMR data.

Some time ago, we published the results of calculations for the molecular structure of a stacking trimer of nucleic acid base pairs [12].

The aim of the present work is to reveal the peculiarities of molecular and electronic structures and energy characteristics of nanoparcticles of nucleic acid components.

\section{Subjects and Methods of Calculations}

We performed $a b$ initio calculations of the molecular and electronic structures of short DNA fragments - stacking $(\mathrm{TpG})(\mathrm{ApC})$ dimer and (TpGpC) (ApCpG) trimer of nucleotide pairs with four $\mathrm{Na}^{+}$ions and without $\mathrm{Na}^{+}$, as well as stacking dimer, trimer, and tetramer of nucleic acid base pairs.

Geometries of the stacking (AC)(TG) dimer of base pairs, (CAC)(GTG) trimer, (ACAC)(TGTG) tetramer, and DNA short fragments were optimized by M06-2x functional of the DFT method [13]. As was shown in [14], this functional describes well the stacking interaction of nucleic acid components. Then, the geometries of dimers and trimers of the base pairs were re-optimized at MP2 level of theory. 6-31/G* basis set was used for the oligomer geometry optimization. The analysis of bond lengths in a dimer calculated by the above methods revealed a difference of $0.1 \%$ in the values of bond lengths.

The analysis of the vibrational spectra of short oligomers showed the absence of imaginary frequencies in the calculated spectra of dimers, trimers, and tetramers. 


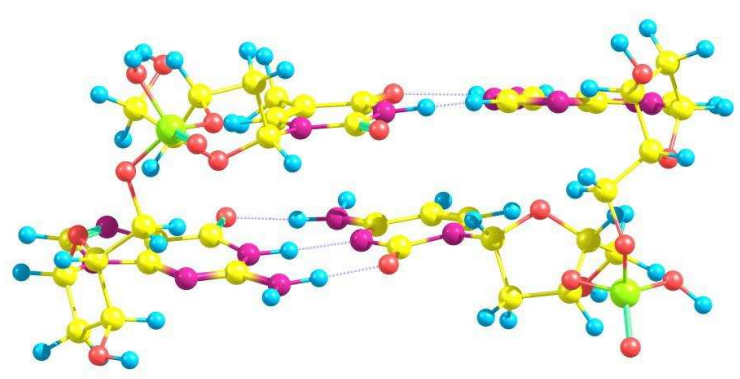

TpA...GpC

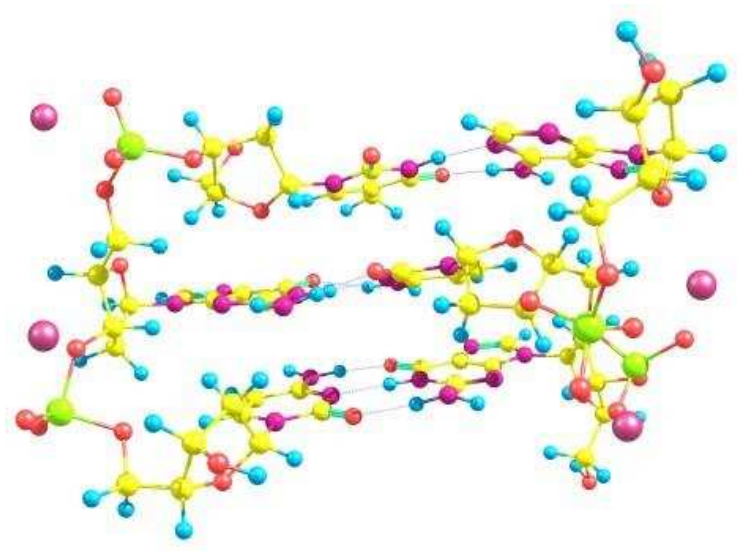

Tp...Ap

Gp...Cp

C...G $+4 \mathrm{Na}^{+}$

Fig. 1. Optimized structures of stacking dimer and trimer of nucleotides

The interaction energies in these structures were determined with the typical scheme described in [4]. According to this scheme, the interaction energy in a complex is equal to the difference between the total energy of the complex and the sum of total energies of monomers. These calculations were performed at MP2 level of theory, BSSE being taken into account and $6-31+\mathrm{G}^{*}$ basis set being applied. The charges on atoms were calculated by the Merz-Kolman method [15]. The calculation of excited state energies had been carried out by the TD DFT method. Here, we used NWChem [1], Gamess [2], and Gaussian 03 [3] programs. The visualization of the results of calculations is performed by the Chem Craft Program [16].

\section{Results and Discussion}

\subsection{Molecular structure of DNA fragments}

When considering the calculation results for molecular structures of a dimer and a trimer of nucleotide pairs (Fig. 1), it should be noted that the calcu- lated $(\mathrm{ApCpG})$ trimer is a codon and is able to code tryptophan aminoacid [17]. Calculations of the molecular structure revealed (Table 1) that, in the structures studied, the average value of interplanar spacing is $3.2 \AA$, the helicity angle in a trimer is $30^{\circ}$, and distances between phosphorus atoms in neighbor chains are $13.1 \AA$, respectively. Intervals between extreme hydrogen atoms in nucleotide pairs and lengths of hydrogen bonds are 15.8 and $1.9 \AA$ on the average, respectively. Comparison of the calculated covalent bond lengths in a dimer and a trimer with the $\mathrm{X}$ ray structure analysis data revealed their difference of about $2 \%$. We calculated the horizontal interactions in the dimer and the trimer under study. These energies are 40 and $69 \mathrm{kcal} / \mathrm{mol}$, respectively. These energies are larger than the total energy of hydrogen bonds, and this is related to the contribution of the cross interactions to the energy of horizontal interactions in oligomers of nucleic acid components (as will be shown below).

\subsection{Molecular structures of nucleic base pair oligomers}

Figure 2 presents the optimized geometries calculated for the stacking $(\mathrm{AC})(\mathrm{TG})$ dimer, $(\mathrm{CAC})(\mathrm{GTG})$ trimer, and (ACAC)(TGTG) tetramer of nucleic acid base pairs.

Calculations of the stacking dimer, trimer, and tetramer revealed the parameters of structures presented in Table 2.

The interplanar distance in the structures is $3.2 \AA$ on the average.

The value of helical twist in the structures lies in the $0-10^{\circ}$ interval (at first, $40^{\circ}$ angle was specified).

The value of propeller twist between bases of the studied structures is in the $3-20^{\circ}$ interval. The value of propeller twist in base pairs of the dimer is larger than that in the trimer.

T a b l e 1. Geometry Parameters of Nucleic Acid

\begin{tabular}{lcc}
\hline \multicolumn{1}{c|}{ Parameters } & Dimer & Trimer \\
\hline $\begin{array}{l}\text { Interplanar distance, } \AA \\
\text { Helical angle, degrees } \\
\text { Distance between } \mathrm{P} \text { atoms in }\end{array}$ & 3.2 & 3.2 \\
$\begin{array}{l}\text { adjacent chains, } \AA \\
\text { Distance between } \mathrm{Na}^{+} \text {ions in } \\
\text { adjacent chains, } \AA\end{array}$ & 13.1 & 13.2 \\
$\begin{array}{l}\text { Horizontal interaction energies, } \\
\text { kcal/mol }\end{array}$ & 15.8 \\
\hline * This calculation is performed for a trimer without $\mathrm{Na}^{+}$ions
\end{tabular}


Base pairs in the structures are nonplanar. The value of dihedral angle between base planes changes within $160-180^{\circ}$.

Middle pairs in the trimer and in the tetramer are more planar (the dihedral angle and the propeller one are equal to 0) than outside ones. On the whole, pairs in the trimer are more planar than those in the dimer. This is an important peculiarity of the molecular structure calculated for the trimer and the tetramer.

\subsection{Interactions in stacking oligomers of base pairs}

We performed calculations of the vertical and horizontal interactions in the oligomers under study. The vertical interaction energies between AT and CG pairs are equal to $-12.02 \mathrm{kcal} / \mathrm{mol}$ in a dimer and $-10.98 \mathrm{kcal} / \mathrm{mol}$ (between high and middle pairs) or $-11.0 \mathrm{kcal} / \mathrm{mol}$ (between middle and down pairs) in a trimer, respectively. These data correlate with results of work [2], in which the parameters of the vertical interactions in stacking dimers of base pairs were calculated by the complete basis set extrapolation.

It is of interest to evaluate the energies of horizontal interactions in the studied structures. Table 3 presents the calculation results for the energies of horizontal interactions in the oligomers and the sums of hydrogen bond energies in AT and GC pairs forming these oligomers. Our calculations of the energies of hydrogen bonds in isolated pairs of AT and GC gave $-13.83 \mathrm{kcal} / \mathrm{mol}$ for AT and $-26.98 \mathrm{kcal} / \mathrm{mol}$ for GC pairs. As is seen from Table 3, the energies of horizontal interactions exceed the arithmetic sum of the energies of hydrogen bonds in isolated AT and GC pairs. These overridings are equal

T a b l e 2. Structural parameters of calculated stacking dimer, trimer, and tetramer

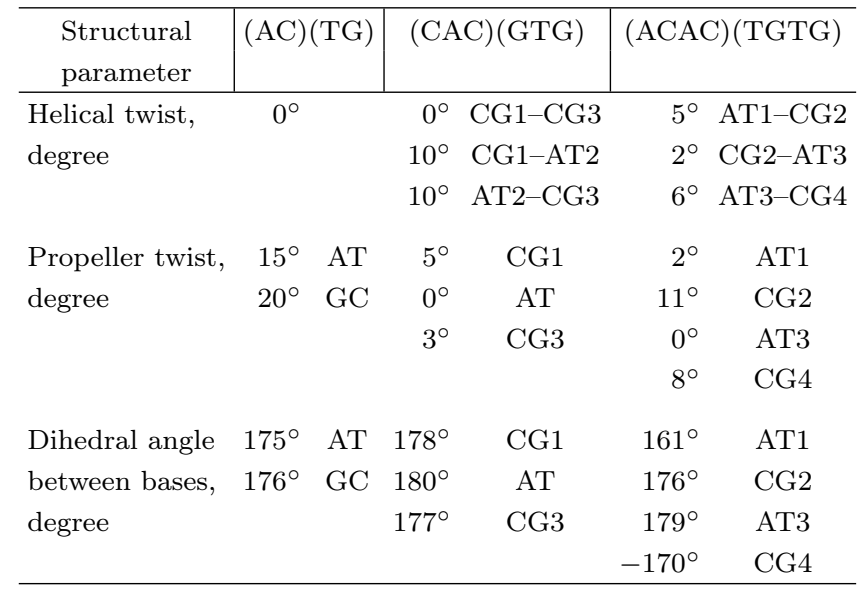

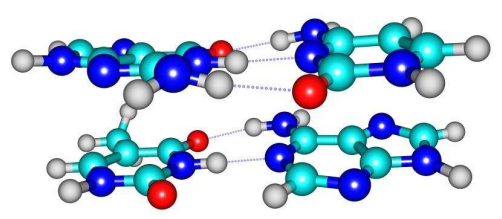

$(\mathrm{AC})(\mathrm{TG})$

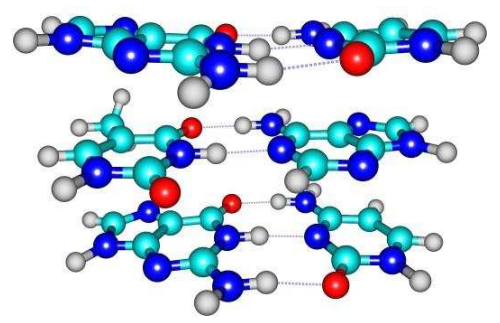

(CAC) (GTG)

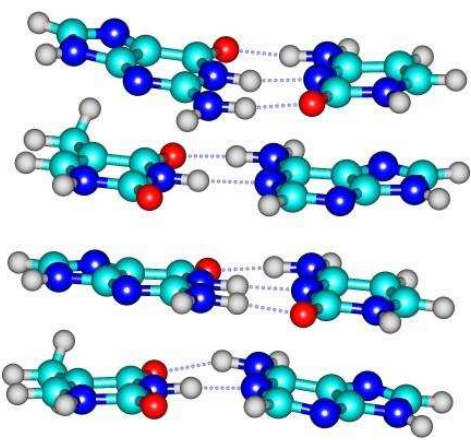

$(\mathrm{CACA}(\mathrm{GTGT}))$

Fig. 2. Optimized structures of the stacking (AC) (TG) dimer, (CAC) (GTG) trimer, and (ACAC) (TGTG) tetramer of nucleic base pairs

to $-2.7 \mathrm{kcal} / \mathrm{mol},-9.39 \mathrm{kcal} / \mathrm{mol}$, and $-13.1 \mathrm{kcal} / \mathrm{mol}$ for the dimer, trimer, and tetramer, respectively.

To explain the contradiction revealed between the energies of horizontal interactions and the sum of the energies of hydrogen bonds in base pairs forming the oligomers, we used the idea of cross interactions [18] and calculated the energies of cross interactions in the systems under study. Cross interactions are induced by

T a b l e 3. Energies of horizontal interactions (kcal/mol) in the stacking (AC)(TG) dimer, (CAC)(GTG) trimer, and (ACAC)(TGTG) tetramer calculated by various methods $\left(6-31+G^{*}\right.$ basis set) and the sums of the energies of H-bonds $(\mathrm{kcal} / \mathrm{mol})$ in isolated base pairs

\begin{tabular}{c|c|c|c}
\hline $\begin{array}{c}\text { Oligomer/ } \\
\text { Method }\end{array}$ & MP2//MP2 & MP2//M06-2X & $\begin{array}{c}\text { Sums of H-bond } \\
\text { energies }\end{array}$ \\
\hline Dimer & -42.62 & -43.51 & -40.81 \\
Trimer & & -77.18 & -67.79 \\
Tetramer & & -94.72 & -81.62 \\
\hline
\end{tabular}




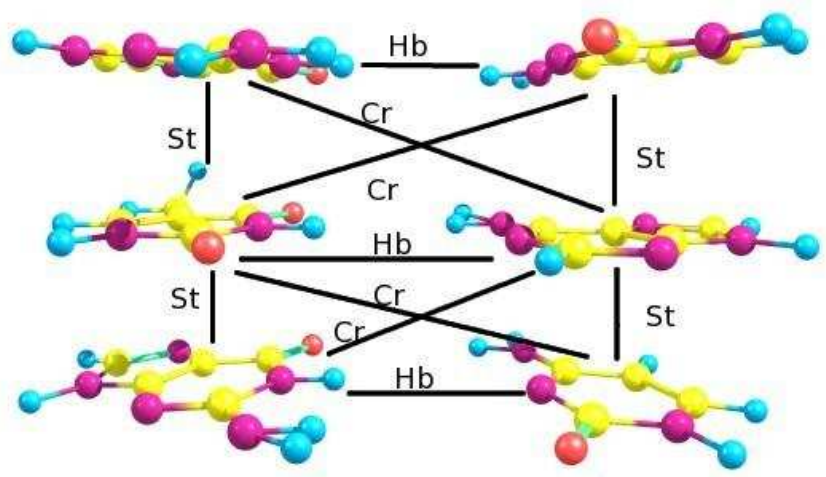

Fig. 3. Calculated scheme of interactions in the trimer. Assignations: $\mathrm{H}-\mathrm{b}$ - hydrogen bonds, St -stacking interactions, $\mathrm{Cr}-$ cross-interactions

Coulomb, dispersion, and inductive interactions and include interactions of every present base with not only the nearest base, but with other ones in a stack or in a helix (Figure 3).

So, the horizontal interaction energies must include $\mathrm{H}-$ bond energies and cross interaction energies. The vertical interaction energies must include stacking interaction and cross interaction energies.

\subsection{Dimer}

Table 4 presents the calculation data on the energy of horizontal interaction in the dimer of base pairs, energies of hydrogen bonds in base pairs in the dimer configuration, energies of the vertical interaction between AT and CG base pairs, energies of stacking interactions in the dimers of bases, being a part of the base pair dimer, as well as the energies of interactions between bases, being a part of different pairs (cross energies). In all these calculations, the geometry of bases was taken into account, which they possessed in the base pair dimer composition. As stated above, the dimer geometry was optimized at MP2 level of theory.

The following designations are accepted in Table 4. The second column (lines 1 and 4) presents the schemes of relative positions of nucleic acid bases - adenine (A), thymine $(\mathrm{T})$, guanine $(\mathrm{G})$, and cytosine $(\mathrm{C})$ in the calculated stacking dimer of nucleic acid base pairs. This column also shows the schemes of relative positions of nucleic bases in $(A)(T),(G)(C)$ base pairs, in stacking dimers of $(\mathrm{A})(\mathrm{C})$ and $(\mathrm{T})(\mathrm{G})$ pairs, and in cross pairs $(\mathrm{A})(\mathrm{G})$ and $(\mathrm{T})(\mathrm{C})$. Horizontal arrows (line 1) mark the horizontal interaction breakdown in the stacking dimer of base pairs. Horizontal arrows in lines 2 and 3 point to the opening of hydrogen bonds in $(\mathrm{A})(\mathrm{T})$ and $(\mathrm{G})(\mathrm{C})$ base pairs. Underlining in schemes (lines 4, 5, 6) shows the stacking interaction failure in the dimers. The third column presents the interaction energies calculated for the structures shown in column 2. Column 4 gives the summation results for hydrogen bond energies and cross

$\mathrm{T}$ a b l e 4. Energies of interactions between components inside the stacking (AC)(TG) dimer (MP2//MP2 method, 6-31 $+G^{*}$ basis set)

\begin{tabular}{|c|c|c|c|}
\hline No. & $\begin{array}{c}\text { Schemes }^{a} \text { of structures } \\
\text { calculated }\end{array}$ & $\begin{array}{c}\text { Interaction energies, } \\
\mathrm{kcal} / \mathrm{mol}\end{array}$ & $\begin{array}{l}\mathrm{Sums}^{g}, \\
\mathrm{kcal} / \mathrm{mol}\end{array}$ \\
\hline 1 & $\begin{aligned}(\mathrm{A}) & \leftrightarrow(\mathrm{T})^{b} \\
(\mathrm{C}) & \leftrightarrow(\mathrm{G})\end{aligned}$ & $-42.46^{*}$ & -42.86 \\
\hline 2 & $\begin{array}{l}(\mathrm{A})(\mathrm{T})^{c} \\
(\ldots)(\ldots)\end{array}$ & -12.80 & \\
\hline 3 & $\begin{array}{c}(\ldots)(\ldots)^{c} \\
(\mathrm{C}) \stackrel{(\mathrm{G})}{\longleftrightarrow}\end{array}$ & -26.31 & \\
\hline 4 & $\frac{(\mathrm{A})(\mathrm{T})}{(\mathrm{C})(\mathrm{G})}^{d}$ & $-12.02^{* *}$ & -12.39 \\
\hline 5 & $\frac{(\mathrm{A})(\ldots)^{e}}{(\mathrm{C})(\ldots)}$ & -3.88 & \\
\hline 6 & 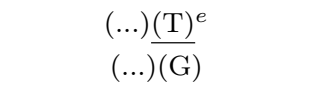 & -4.77 & \\
\hline 7 & $\begin{array}{c}(\mathrm{A})(\ldots)^{f} \\
(\ldots)(\mathrm{G})\end{array}$ & -3.73 & \\
\hline 8 & $\begin{array}{c}(\ldots)(\mathrm{T})^{f} \\
(\mathrm{C})(\ldots)\end{array}$ & -0.01 & \\
\hline
\end{tabular}

a Scheme of the $(\mathrm{AC})(\mathrm{TG})$ stacking dimer in this Table is $(\mathrm{A})(\mathrm{T})$ (C) $(\mathrm{G})$

${ }^{b}$ Scheme $(\mathrm{A}) \leftrightarrow(\mathrm{T})$ means the breaking of the horizontal inte$(\mathrm{C}) \leftrightarrow(\mathrm{G})$

raction in the $(\mathrm{AC})(\mathrm{TG})$ stacking dimer.

$c$ Schemes $\begin{gathered}(A) \leftrightarrow(T) \\ (\ldots)(\ldots)\end{gathered}$ and $\begin{gathered}(\ldots)(\ldots) \\ (\mathrm{C}) \leftrightarrow(\mathrm{G})\end{gathered}$ show the breaking of the H-bond interaction in AT and CG pairs in the (AC)(TG) stacking dimer. Geometries of these AT

and GC pairs are identical to ones in the studied dimers.

$d$ Scheme $\frac{(\mathrm{A})(\mathrm{T})}{(\mathrm{C})(\mathrm{G})}$ shows the breaking of the stacking interaction between $\mathrm{AT}$ and $\mathrm{GC}$ pairs in $(\mathrm{AC})(\mathrm{TG})$ stacking dimer.

e Schemes $\frac{(\mathrm{A})(\ldots)}{(\mathrm{C})(\ldots)}$ and $\quad \ldots(\mathrm{T}) \frac{(\mathrm{T})}{(\mathrm{G})}$ show the breaking of the stacking interactions in the stacking $\mathrm{AC}$ and $\mathrm{TG}$ dimers as a compo- nent of the (AC)(TG) stacking dimer of base pairs. The geomet-

ries of these $\mathrm{AC}$ and $\mathrm{TG}$ dimers are identical to ones in the $(\mathrm{AC})(\mathrm{TG})$ dimer.

$f$ Schemes $(\mathrm{A})(\ldots)$ and $(\ldots)(\mathrm{T})$ show the breaking of cross interactions in the $(\mathrm{AC})(\mathrm{TG})$ stacking dimer between $\mathrm{A}$ and $\mathrm{G}$ and between $\mathrm{T}$ and $\mathrm{C}$, respectively.

$g$ Sums of all possible interactions (H-bonds, stacking and cross interactions) of components are shown. 
interaction energies (line 1) and for stacking and cross interaction energies (line 4) in the calculated base pair dimer. It should be noted that the energy of hydrogen bonds in AT and GC pairs being a part of the dimer is lower than that of hydrogen bonds in isolated AT and GC pairs, which is related to the different geometries of these pairs in the dimer composition and in the free state.

As Table 4 shows (column 3), the energy of horizontal interaction in the dimer is by $3.35 \mathrm{kcal} / \mathrm{mol}$ higher than the arithmetic sum of the energies of hydrogen bonds in AT and CG base pairs in the dimer. The energy of vertical interaction in the dimer between AT and CG pairs is more than the arithmetic sum of the interaction energies in the dimers of $\mathrm{AC}$ and $\mathrm{TG}$ bases, being a part of the stacking base pair dimer.

As is noted above, this difference is probably caused by the cross interactions. Really, the calculations of the interaction energies between bases lying in different planes (cross energies) result in the values of -3.73 $\mathrm{kcal} / \mathrm{mol}$ and $-0.01 \mathrm{kcal} / \mathrm{mol}$ for AG and TC pairs, respectively. Taking these interactions into account allows one to reach a rather good agreement between the horizontal and vertical interaction energies and the sums of energies between monomers in the stacking dimer (most right column in Table 4). Differences between the total energy calculated for horizontal interactions in the dimer and the arithmetic sum of hydrogen bonds in base pairs and of cross interactions are within 1\%, similar to the difference being about $3 \%$ for the vertical interaction.

So, the presence of the cross interaction explains a rise of the horizontal and vertical interaction energies in the stacking dimer, in comparison with the sum of the energies of hydrogen bonds in base pairs and the sum of the energies of stacking interactions in the dimers of bases.

\subsection{Interactions in the trimer and the tetramer}

The same situation is observed both for the trimer and the tetramer. Table 5 presents the energies of horizontal interaction in the trimer of base pairs, energies of hydrogen bonds in base pairs in the trimer, energies of vertical interactions between AT and CG base pairs, and energies of stacking interaction in the dimers of bases, being a part of the trimer, as well as the energies of interactions between bases forming different pairs (cross interaction energies). In all these calculations, the geometry of bases was used, which they have in the trimer structure. In addition, Table 5 presents the results of summation of hydrogen bond energies (rightmost column) and of the energies of $\mathrm{AG}$ and $\mathrm{TC}$ cross interactions in the trimer (above) and the results of summation of stacking interaction energies in the dimers of AC and TG bases forming the studied stacking trimer of $(\mathrm{CAC})(\mathrm{GTG})$ base pairs and the energies of $\mathrm{AG}$ and $\mathrm{TC}$ cross interactions.

It should be noted that the energies of hydrogen bonds in AT and GC pairs in the trimer differs both from those of hydrogen bonds in the dimer and in isolated AT and GC pairs, which is determined by a difference in the geometries of these pairs in the trimer, dimer, and in the free state (Table 2). As is seen from Table 5, the calculations revealed that the energy of horizontal interaction in the stacking trimer exceeds the arithmetic sum of the hydrogen bond energies in isolated AT and GC pairs. The excess makes up $-10.84 \mathrm{kcal} / \mathrm{mol}$. Energies of the vertical interactions in the trimer between AT and CG pairs are larger than the arithmetic sums of interaction energies in the dimers of bases - AC and TG being a part of the stacking trimer composition.

The calculations of interaction energies of the bases placed in various planes (cross interaction energies) resulted in $-4.39 \mathrm{kcal} / \mathrm{mol}$ and $-4.47 \mathrm{kcal} / \mathrm{mol}$ for $\mathrm{GA}$ and AG pairs and $-0.63 \mathrm{kcal} / \mathrm{mol}$ for $\mathrm{CT}$ and TC pairs, respectively. There is some difference of interaction energies for reciprocal GA and AG pairs. Table 5 also presents the energies of cross interactions between bases (adenine and guanine) in the GAG triad and cytosine and thymine in the CTC triad of the stacking trimer under study. Just taking these cross interactions into account allows us to reach a very good agreement between the total energy of horizontal interactions and the sum of the energies of interactions between monomers (nucleic acid bases) in the trimer.

Table 5 shows the energies of vertical interactions between the upper GC and middle AT pairs and between middle AT and down GC pairs, which are only by about $0.7 \mathrm{kcal} / \mathrm{mol}$ lower than the summation results for stacking and cross interactions of components in these structures. Thus, as in the dimer case, the consideration of the cross interaction explains a rise of the energy of horizontal and vertical interactions in the base pair trimer in comparison with the sum of the energies of hydrogen bonds in base pairs and with the sum of stacking interactions in dimers of bases, being the part of the trimer.

Let us consider the interaction energies for the tetramer. Table 1 from Supplement presents the calculation results (column 3) for the total energy of horizontal interaction in the tetramer, energies of hydrogen bonds in base pairs being a part of the tetramer, and energies of paired interactions (stacking and cross in- 
T a b l e 5. Energies of interactions between components inside the (CAC)(GTG) trimer (MP2//M06-2X method, $6-31+G^{*}$ basis set)

\begin{tabular}{|c|c|c|c|c|c|c|c|}
\hline No. & $\begin{array}{c}\text { Schemes of structures } \\
\text { calculated }^{a}\end{array}$ & $\begin{array}{c}\text { Interaction energies, } \\
\mathrm{kcal} / \mathrm{mol}\end{array}$ & $\begin{array}{l}\text { Sums }{ }^{b}, \\
\mathrm{kcal} / \mathrm{mol}\end{array}$ & No. & $\begin{array}{c}\text { Schemes of structures } \\
\text { calculated }{ }^{a}\end{array}$ & $\begin{array}{c}\text { Interaction energies, } \\
\mathrm{kcal} / \mathrm{mol}\end{array}$ & $\begin{array}{l}\text { Sums }{ }^{b}, \\
\mathrm{kcal} / \mathrm{mol}\end{array}$ \\
\hline \multirow[t]{3}{*}{1} & $(\mathrm{C}) \longleftrightarrow(\mathrm{G})$ & -77.18 & $-76.46^{c}$ & 9 & $(\ldots)(\mathrm{G})$ & -4.17 & \\
\hline & $(\mathrm{A}) \longleftrightarrow(\mathrm{T})$ & & $-77.16^{d}$ & & $(\ldots) \overline{(\mathrm{T})}$ & & \\
\hline & $(\mathrm{C}) \longleftrightarrow(\mathrm{G})$ & & & & $(\ldots)(\ldots)$ & & \\
\hline \multirow[t]{3}{*}{2} & $(\mathrm{C}) \longleftrightarrow(\mathrm{G})$ & $10^{3}$ & 0.8170 & 10 & $(\ldots)(\ldots)$ & -4.19 & \\
\hline & $(\ldots)(\ldots)$ & & & & $(\ldots)(\mathrm{T})$ & & \\
\hline & $(\ldots)(\ldots)$ & & & & $(\ldots) \overline{(\mathrm{G})}$ & & \\
\hline \multirow[t]{3}{*}{3} & $(\ldots)(\ldots)$ & -26.61 & & 11 & $(\ldots)(\ldots)$ & -4.47 & \\
\hline & $(\ldots)(\ldots)$ & & & & $(\mathrm{A})(\ldots)$ & & \\
\hline & $(\mathrm{C}) \longleftrightarrow(\mathrm{G})$ & 10.0 & 0.87273 & & $(\ldots)(\mathrm{G})$ & & \\
\hline \multirow[t]{3}{*}{4} & $(\ldots)(\ldots)$ & -13.11 & & 12 & $(\ldots)(\mathrm{G})$ & -4.39 & \\
\hline & $(\mathrm{A}) \longleftrightarrow(\mathrm{T})$ & & & & $(\mathrm{A})(\ldots)$ & & \\
\hline & $(\ldots)(\ldots)$ & & & & $(\ldots)(\ldots)$ & & \\
\hline \multirow[t]{3}{*}{5} & $(\mathrm{C})(\mathrm{G})$ & -11.00 & -11.70 & 13 & $(\ldots)(\mathrm{G})^{e}$ & -9.38 & \\
\hline & $\overline{(\mathrm{A})(\mathrm{T})}$ & & & & $(\mathrm{A})(\ldots)$ & & \\
\hline & $(\mathrm{C})(\mathrm{G})$ & & & & $(\ldots)(\mathrm{G})$ & & \\
\hline \multirow[t]{3}{*}{6} & $(\mathrm{C})(\mathrm{G})$ & -10.98 & -11.72 & 14 & $(\mathrm{C})(\ldots)^{f}$ & -1.44 & \\
\hline & $(\mathrm{A})(\mathrm{T})$ & & & & $(\ldots)(\mathrm{T})$ & & \\
\hline & $\overline{(C)(G)}$ & & & & $(\mathrm{C})(\ldots)$ & & \\
\hline \multirow[t]{3}{*}{7} & $(\mathrm{C})(\ldots)$ & -2.51 & & 15 & $(\ldots)(\ldots)$ & -0.63 & \\
\hline & $\overline{(\mathrm{A})}(\ldots)$ & & & & $(\ldots)(\mathrm{T})$ & & \\
\hline & $(\ldots)(\ldots)$ & & & & $(\mathrm{C})(\ldots)$ & & \\
\hline \multirow[t]{3}{*}{8} & $(\ldots)(\ldots)$ & -2.43 & & 16 & $(\mathrm{C})(\ldots)$ & -0.63 & \\
\hline & $(\mathrm{A})(\ldots)$ & & & & $(\ldots)(\mathrm{T})$ & & \\
\hline & $\overline{(C)}(\ldots)$ & & & & $(\ldots)(\ldots)$ & & \\
\hline
\end{tabular}

$(\mathrm{C}) \leftrightarrow(\mathrm{G})$

${ }^{a}$ Scheme of the $(\mathrm{CAC})(\mathrm{GTG})$ stacking trimer in this table is $(\mathrm{A}) \leftrightarrow(\mathrm{T})$. Other designations in this Table are similar to those in $(\mathrm{C}) \leftrightarrow(\mathrm{G})$

Table 4. Horizontal interaction in this Table is between (CAC) and (GTG) stacking trimers of nucleic bases. Stacking interactions are between the upper CG pair and (AC) (GT) components and between $(\mathrm{CA})(\mathrm{GT})$ and the down CG pair.

${ }^{b}$ Sums of all possible interactions (H-bonds, stacking and cross interactions) of the components.

${ }^{c}$ Sum of H-bond interactions with using separate GA, AG, CT and TC (lines 11, 12, 14, 15) cross interactions.

${ }^{d}$ Sum of H-bond interactions together with GAG (line13) and CTC (line 16) cross interactions.

teractions) in the tetramer. As in the cases of dimer and trimer, the energies of horizontal and vertical interactions exceed the arithmetic sum of the energies of hydrogen bonds and stacking interactions in pairs and the dimers of bases being in the tetramer. Nevertheless, the consideration of the cross interactions in cross pairs and triads of bases present in the tetramer allows us to "compensate" this difference.

It is worth noting the variability of the energies of cross interactions in AG and TC pairs in the tetramer. The energies of cross interactions change from -4.12 $\mathrm{kcal} / \mathrm{mol}$ to $-4.70 \mathrm{kcal} / \mathrm{mol}$ and from $-0.42 \mathrm{kcal} / \mathrm{mol}$ to $-0.81 \mathrm{kcal} / \mathrm{mol}$ for $\mathrm{AG}$ and $\mathrm{CT}$ pairs, respectively. This variability is related to the difference in the spatial structures of complementary AT and GC base pairs (in particular, with the difference in dihedral and propeller angles, which include AG and CT "cross pairs" (see Table 2)).

In addition, we calculated the energies necessary for the "opening" of end AT and GC base pairs, being a part of the tetramer. The values of energies were -23.36 $\mathrm{kcal} / \mathrm{mol}$ and $-37.49 \mathrm{kcal} / \mathrm{mol}$ for AT and GC pairs, respectively. The values of energies calculated directly for end pair openings are close to those of the sum of the energies of hydrogen bonds in base pairs, as well as the energies of cross and stacking interactions between the nearest bases of nucleic pairs in the tetramer. The calculations of the opening energy of the outer GC pair in 


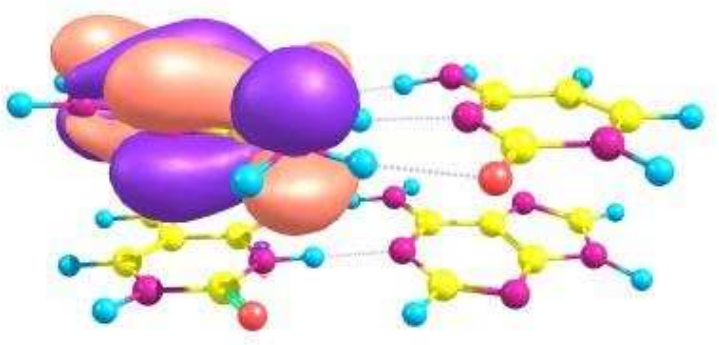

HOMO

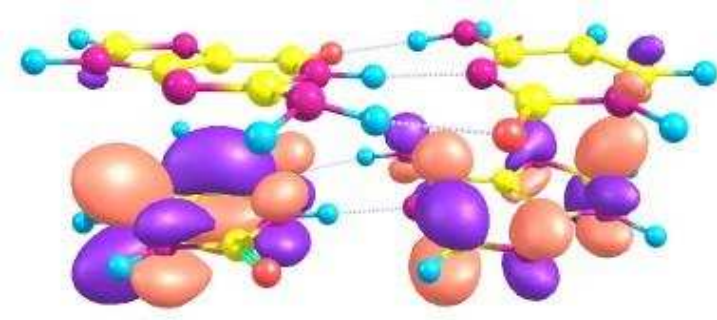

$\mathrm{LUMO}+6$

Fig. 4. Molecular orbitals (HOMO and LUMO+6), between which the first electronic transition occurs in the dimer

T a b l e 6 . Total charges of base stacks in the (AC)(TG) dimer, (CAC)(GTG) trimer, and (ACAC) (TGTG) tetramer

\begin{tabular}{c|c}
\hline $\begin{array}{c}\text { Stacks of nucleobases } \\
\text { in oligomers }\end{array}$ & $\begin{array}{c}\text { Total charges in stacks of } \\
\text { nucleobases }\end{array}$ \\
\hline$(\mathrm{AC})$ & 0.115 \\
$(\mathrm{TG})$ & -0.115 \\
$(\mathrm{CAC})$ & 0.229 \\
$(\mathrm{GTG})$ & -0.229 \\
$(\mathrm{ACAC})$ & 0.243 \\
$(\mathrm{TGTG})$ & -0.243 \\
\hline
\end{tabular}

the tetramer and the trimer gave similar results: -37.49 $\mathrm{kcal} / \mathrm{mol}$ and $-37.98 \mathrm{kcal} / \mathrm{mol}$ for the tetramer and the trimer, respectively.

The analysis of Tables $3-5$ and Table 1 in Supplement allowed us to reveal increasing the relative contribution of cross interactions to the total horizontal interactions in the structures under study. This contribution increases from $7.9 \%$ for the dimer to $18.4 \%$ for the tetramer.

\subsection{Charges}

The analysis of the electronic structure of oligomers (in particular, the analysis of the electronic density distribution) is of special interest. The calculations of the charges on atoms (Table 6) showed that the sum of charges in stacks of (AC)and(TG), (CAC) and (GTG), (ACAC) and (TGTG) bases forming the oligomers under study is not equal to 0 and comes to $0.115,0.229$, and 0.243 for the dimer, trimer, and tetramer, respectively. It is a manifestation of the charge transfer in the horizontal direction in the short stacking oligomers.

\subsection{Excited states}

The analysis of excited states in the structures is of significant interest as well. The calculations of the excited
T a b l e 7. Parameters of dimer (left) and trimer (right) excited states calculated by the TD DFT method on MP2 level of theory calculated geometries

\begin{tabular}{c|c|c|c|c|c|c}
\hline $\begin{array}{c}\text { Excited } \\
\text { state }\end{array}$ & $\begin{array}{c}\text { Excited } \\
\text { state } \\
\text { energies, } \\
\text { eV, dimer }\end{array}$ & $\begin{array}{c}\text { Wave } \\
\text { length, } \\
\mathrm{nm}\end{array}$ & $\begin{array}{c}\text { Oscil. } \\
\text { strength }\end{array}$ & $\begin{array}{c}\text { Excited } \\
\text { state } \\
\text { energies, } \\
\text { eV, trimer }\end{array}$ & $\begin{array}{c}\text { Wave } \\
\text { length, } \\
\mathrm{nm}\end{array}$ & $\begin{array}{c}\text { Oscil. } \\
\text { strength }\end{array}$ \\
\hline 1 & 4.70 & 263.4 & 0.0040 & 4.60 & 269.1 & 0.0030 \\
2 & 4.86 & 254.9 & 0.012 & 4.64 & 267.1 & 0.0034 \\
3 & 4.91 & 252.6 & 0.038 & 4.69 & 264.2 & 0.0033 \\
4 & 4.94 & 250.1 & 0.016 & 4.75 & 260.7. & 0.0479 \\
5 & 5.05 & 245.3 & 0.001 & 4.76 & 260.3 & 0.0004 \\
6 & 5.12 & 242.3 & 0.008 & 4.81 & 258. & 0.0401 \\
7 & 5.14 & 241.1 & 0.050 & 4.82 & 257.3 & 0.0051 \\
8 & 5.17 & 239.7 & 0.282 & 4.82 & 257.0 & 0.0132 \\
9 & 5.24 & 236.3 & 0.101 & 4.95 & 250.0 & 0.001 \\
10 & 5.36 & 231.2 & 0.243 & 4.99 & 248.21 & 0.0558 \\
\hline
\end{tabular}

state energies in the stacking dimer and trimer revealed a possibility for a low-intensity band to exist in the longwave region of the spectrum (Table 7). This corresponds to our previous suppositions [19] on possible chargeresonance interactions in crystals and dimers of nucleic acid bases, as well as to the data of work [20]. The analysis of molecular orbitals in the dimer showed (Fig. 4) that this low-frequency transition has to take place between the molecular orbital localized on guanine and the molecular orbital localized on the neighboring pair of bases (thymine and adenine). Thus, we deal with the electronic transition between two systems of molecules being placed one over another. Moreover, in the trimer case, we can observe several low-intensity electronic transitions in the low-energy region of the spectrum.

\section{Conclusions}

1. The ab initio calculations of nanoparticles of nucleic acids components - a dimer and a trimer of nucleotides 
$\mathrm{T}$ a b l e 8. Energies of interactions between components inside a tetramer (MP2//M06-2X computation method)

\begin{tabular}{|c|c|c|c|c|c|}
\hline No. & $\begin{array}{c}\text { Schemes } \\
\text { structures } \\
\text { calculated }\end{array}$ & $\begin{array}{c}\text { Interaction } \\
\text { energies, } \\
\mathrm{kcal} / \mathrm{mol}\end{array}$ & No. & $\begin{array}{c}\text { Schemes } \\
\text { structures } \\
\text { calculated }\end{array}$ & $\begin{array}{c}\text { Interaction } \\
\text { energies, } \\
\mathrm{kcal} / \mathrm{mol}\end{array}$ \\
\hline 1 & $\begin{array}{l}(\mathrm{A}) \longleftrightarrow(\mathrm{T}) \\
(\mathrm{C}) \longleftrightarrow(\mathrm{G}) \\
(\mathrm{A}) \longleftrightarrow(\mathrm{T}) \\
(\mathrm{C}) \longleftrightarrow(\mathrm{G})\end{array}$ & -94.72 & 9 & $\begin{array}{l}(\ldots)(\mathrm{T}) \\
(\mathrm{C})(\ldots) \\
(\ldots)(\ldots) \\
(\ldots)(\ldots)\end{array}$ & 0.42 \\
\hline 2 & $\begin{array}{c}(\ldots)(\ldots) \\
(\mathrm{C}) \longleftrightarrow(\mathrm{G}) \\
(\ldots)(\ldots) \\
(\ldots)(\ldots)\end{array}$ & -26.79 & 10 & $\begin{array}{l}(\ldots)(\mathrm{T}) \\
(\mathrm{C})(\ldots) \\
(\ldots)(\mathrm{T}) \\
(\ldots)(\ldots)\end{array}$ & -0.81 \\
\hline 3 & $\begin{array}{c}(\ldots)(\ldots) \\
(\ldots)(\ldots) \\
(\ldots)(\ldots) \\
(\mathrm{C}) \longleftrightarrow(\mathrm{G})\end{array}$ & 26.44 & 11 & $\begin{array}{l}(\ldots)(\ldots) \\
(\mathrm{C})(\ldots) \\
(\ldots)(\mathrm{T}) \\
(\mathrm{C})(\ldots)\end{array}$ & -0.76 \\
\hline 4 & $\begin{array}{c}(\mathrm{A}) \longleftrightarrow(\mathrm{T}) \\
(\ldots)(\ldots) \\
(\ldots)(\ldots) \\
(\ldots)(\ldots)\end{array}$ & -12.03 & 12 & $\begin{array}{l}(\mathrm{A})(\ldots) \\
(\mathrm{C})(\ldots) \\
(\ldots)(\ldots) \\
(\ldots)(\ldots)\end{array}$ & -2.59 \\
\hline 5 & $\begin{array}{c}(\ldots)(\ldots) \\
(\ldots)(\ldots) \\
(\mathrm{A}) \longleftrightarrow(\mathrm{T}) \\
(\ldots)(\ldots)\end{array}$ & -12.04 & 13 & $\begin{array}{l}(\ldots)(\ldots) \\
(\ldots)(\ldots) \\
(\mathrm{A})(\ldots) \\
(\mathrm{C})(\ldots)\end{array}$ & -2.446 \\
\hline 6 & $\begin{array}{l}(\mathrm{A})(\ldots) \\
(\ldots)(\mathrm{G}) \\
(\ldots)(\ldots) \\
(\ldots)(\ldots)\end{array}$ & -4.70 & 14 & $\begin{array}{l}(\ldots)(\ldots) \\
(\ldots)(\ldots) \\
(\ldots)(\mathrm{T}) \\
(\ldots)(\mathrm{G})\end{array}$ & -3.64 \\
\hline 7 & $\begin{array}{l}(\ldots)(\ldots) \\
(\ldots)(\ldots) \\
(\mathrm{A})(\ldots) \\
(\ldots)(\mathrm{G})\end{array}$ & -4.35 & 15 & $\begin{array}{l}(\ldots)(\mathrm{T}) \\
(\ldots)(\mathrm{G}) \\
(\ldots)(\ldots) \\
(\ldots)(\ldots)\end{array}$ & -2.55 \\
\hline 8 & $\begin{array}{l}(\ldots)(\ldots) \\
(\ldots)(\mathrm{G}) \\
(\mathrm{A})(\ldots) \\
(\ldots)(\ldots)\end{array}$ & -4.12 & & & \\
\hline
\end{tabular}

Assignations are the same as in Tables 4 and 5.

and a stacking trimer and a stacking tetramer of nucleic bases have been carried out for the first time.

2. The calculations performed revealed peculiarities of the structure and the interaction energy of nanoparticles: - Cross interactions play a considerable role in the stabilization of the structures. The contribution of cross interactions into horizontal interactions grows with the lengthening of the oligomer.

- Internal pairs of bases in a trimer and a tetramer of base pairs are more planar in comparison with external ones.

- Nanoparticle components get electric charges in nanoparticles.
- Low-intensity long-wave bands can appear in the electronic spectra of nanoparticles.

The authors thank Dr. S. Stepanian and Dr. R. Zybatyuk for their help in calculations. We appreciate the Institute of Cybernetics of NASU, Institute of Theoretical Physics of NASU, Institute of Single Crystals of NASU, Moscow State University, and Institute for Low Temperature Physics and Engineering of NASU for softwares and the computer time given.

\section{Supplement}

See Table 8 .

1. E.J. Bylaska et al., NWChem, A Computational Chemistry Package for Parallel Computers, Version 5.1 (Pacific Northwest Nat. Lab., Richland, 2007).

2. M.S. Gordon and M.W. Schmidt, in Theory and Applications of Computational Chemistry: the First Forty Years, edited by C.E. Dykstra, G. Frenking, K.S. Kim, and G.E. Scuseria (Elsevier, Amsterdam, 2005), p. 1167.

3. M.J. Frisch et al., Gaussian 03, Revision E.01 (Gaussian, Wallingford, CT, 2004).

4. P. Hobza and J. Sponer, J. Chem. Rev. 99, 3247 (1999) and references therein.

5. P. Jurecka and P. Hobza, J. Am. Chem. Soc. 125, 15608 (2003).

6. P. Jurecka, J. Sponer, J. Cerny, and P. Hobza, Phys. Chem. Chem. Phys. 8, 1985 (2006).

7. J. Sponer, P. Jurecka, I. Marchan, F.J. Leque, M. Orozco, and P. Hobza, Europ. J. Chem. 12, 2854 (2006).

8. M. Kabelac, E.C. Sherer, C.J. Cramer, and P. Hobza, Europ. J. Chem. 13, 2067 (2007).

9. M. Kabelac, H. Valdes, E.C. Sherer, C.J. Cramer, and P. Hobza, Phys. Chem. Chem. Phys. 9, 5000 (2007).

10. M. Pitonak, P. Neogrady, and P. Hobza, Phys. Chem. Chem. Phys. 12, 1369 (2010).

11. I. Daübkowska, H. Gonzalez, P. Jurecka, and P.Hobza, J. Phys. Chem. A 109, 1131 (2005).

12. Yu.V. Rubin, L.F. Belous, A.A. Yakuba, A.L. Golovinsky, and Yu.V. Savin, in Proceedings of Int. Conf. "Parallel Comput. Technologies" (YUUGU, Chelyabinsk, 2009), p. 667.

13. Y. Zhao, G. Donald, and D. Truhlar, J. Chem. Phys. 125, 194101/1 (2006).

14. J. Gu, J. Wang, J. Leszczynski, Y. Xie, F. Henry, and H.F. Schaefer, Chem. Phys. Lett. 459, 164 (2008).

15. B. Besler, K. Merz, and P. Kolman, J. Comput. Chem. 11, 431 (1990). 
16. G.A. Zhurko, Chem. Craft. Tool for treatment of chemical data. Version 5.1.

17. W. Saenger, Principles of Nucleic Acid Structures (Springer, New York, 1984).

18. L.D. Landau and E.M. Lifshitz, Quantum Mechanics. Non-Relativistic Theory (Pergamon Press, New York, 1980).

19. Yu.V. Rubin and S.A. Egupov, Biofiz. 32, 377 (1987).

20. J.A. Aquino, D. Nachtigallová, P. Hobza, D.G. Truhlar, C. Haettig, and H. Lischka, J. Comput. Chem. 32, 1217 (2011).

Received 06.10.11

\section{МОЛЕКУЛЯРНА СТРУКТУРА ТА ВЗАЄМОДІЇ \\ У НАНОЧАСТИНКАХ КОМПОНЕНТІВ \\ НУКЛЕЇНОВИХ КИСЛОТ: НЕЕМПІРИЧНІ РОЗРАХУНКИ}

\section{Ю.В. Рубін, Л.Г. Белоус}

$\mathrm{P}$ е з ю м е

Самоасоціати компонентів нуклеїнових кислот (стекинг тримери та тетраметри основ нуклеїнових кислот) та короткі фрагменти нуклеїнових кислот є наночастинками (їхні лінійні розміри більше $10 \AA$ А). Сучасні квантово-механічні методи та про- грами дозволяють здійснювати розрахунки систем, що містять 150-200 атомів, із достатньо великим базисом (наприклад, 6$\left.31 \mathrm{G}^{*}\right)$. Метою роботи є виявлення особливостей молекулярної та електронної структур, енергетичних характеристик наночастинок компонентів нуклеїнових кислот.

Нами виконано неемпіричні розрахунки молекулярної структури та взаємодій в стекинг димері та тримері пар нуклеотидів, а також в стекинг димері, тримері та тетраметрі пар основ нуклеїнових кислот.

Проведені розрахунки молекулярної структури димеру та тримеру пар нуклеотидів показали, що міжплощинна відстань в структурах, що вивчалися, в середньому дорівнювала $3,2 \AA$, кут спіральності в тримері - $30^{\circ}$, відстань між атомами фосфору в сусідніх ланцюгах $13,1 \AA$. Також розраховані енергії горизонтальних взаємодій у цих димерах та тримерах.

Ми зробили детальний аналіз міжплощинних відстаней і кутів між основами та їх парами у стекинг димері, тримері та тетраметрі пар основ нуклеїнових кислот. Аналіз горизонтальних і вертикальних взаємодій в розрахованих коротких олігомерах пар основ нуклеїнових кислот показав значну роль перехресних взаємодій у стабілізації вивчених структур. Внесок перехресних взаємодій в горизонтальні взаємодії збільшується з подовженням олігомеру. Показано, що у складі наночастинок їхні компоненти отримують електричний заряд. В електронних спектрах наночастинок можуть з'явитись довгохвильові малоінтенсивні смуги. 